Available online at $\quad$ http://www.jfas.info

\title{
AN EXPERIMENTAL STUDY ON GOLD PRECIPITATION FROM LEACH SOLUTIONS OF TECHNOGENIC GOLD-BEARING RAW MATERIALS
}

\author{
A. V. Taskin ${ }^{1,}$, A. A. Yudakov², S. I. Ivannikov², O. I. Yelkin ${ }^{1}$, O. S. Danilov ${ }^{1}$, L. N. \\ Alekseyko $^{1}$ \\ ${ }^{1}$ Far Eastern Federal University (FEFU) \\ ${ }^{2}$ Institute of Chemistry - Far Eastern Branch Russian Academy of Sciences
}

Published online: 08 August 2017

\begin{abstract}
This paper presents the results of the study dedicated to the determination of the optimum parameters for the electrolytic gold precipitation from thiourea leach solutions. The leaching was carried out using technogenic gold-bearing raw materials (gold-bearing sands) of the Far East of the Russian Federation. The study focused on the influence of the below parameters of electrolytic precipitation: electrolyte composition, overall cathodic current density, electrode voltage, and structural design of an electrolytic cell. As the results of the experiments, the optimum electrolyte composition and parameters of the current (overall cathodic current density $1000 \mathrm{~A} / \mathrm{m}^{2}$, electrode voltage $6 \mathrm{~V}$ ) were determined. Under these parameters, it is possible to recover up to $93 \%$ of gold from thiourea leach solutions.
\end{abstract}

Keywords: technogenic gold-bearing raw materials, gold, thiourea leaching, electrolyte, cathodic current density, electrolytic cell

\section{INTRODUCTION}

The current situation in the Russia's gold industry is characterized by the dramatic imbalance between the extraction and buildup of stockpiles, deterioration of ore grades, usage of the potential of fields at the level max. $50 \%$, and significant amounts of technogenic wastes.

Author Correspondence, e-mail: taskin@yandex.ru

doi: $\underline{\text { http://dx.doi.org/10.4314/jfas.v9i2s.868 }}$ 
Taking all of the above into consideration, it is necessary to search for effective solutions aimed at the improvement of the production performance indicators, the growth of the resource base, and resolution of environmental problems related to the comprehensive mineral processing. The availability of more than 12 billion tons of gold mining wastes sets a longterm trend towards the recovery of precious metal from recyclable mineral gold-bearing resources by developing the low-waste technologies customized for the processed raw materials. Ash and slag wastes remaining after the burning of coal can be used as another similar technogenic resource for gold recovery. As reported, in some cases, the content of gold in ash may be of interest from a commercial perspective.

There are certain specific aspects related to the technogenic gold-bearing wastes in terms of their technological processing aimed at the recovery of precious metals.

Such raw material resources have the following undeniable advantages: 1) low prime cost of metal supply owing to zero costs for recovery and lower costs for rock breaking, 2) high resource potential (gold reserves contained only in the gold mining technogenic wastes of Primorsky Kray are estimated at 5000 tons, gold reserves contained in ash dumps of Primorsky Kray alone are estimated at 12-16 tons).

Physical and mechanical, as well as structural, features of such wastes predetermine the following disadvantages:

- a number of mineral spots are by an order of magnitude more as compared with the number in traditional crude ores (more than 30000);

- low grade of gold dispersed through the mineral matrix as fine and ultrafine particles in various forms, including disseminated sulfide minerals, of various oxidation levels [1-4].

Therefore, technogenic gold-bearing wastes fall into the category of refractory raw materials. In order to use such raw materials, it is necessary to improve and customize the traditional processing schemes.

One of the advanced technologies in the sphere of hydrometallurgy which makes it possible to effectively extract gold from technogenic refractory composite raw materials is the method of thiourea leaching $[7-10,12]$. This method features the following advantages as compared with the traditional cyanidation:

- $\quad$ higher leaching speed;

- $\quad$ better efficiency of the process when dealing with cyanide-resistant geomaterials;

- $\quad$ less influence of impurity ions as compared with a standard cyanidation process.

The method of adsorption onto activated carbon can be used to extract gold and silver from acid thiourea solutions with the relatively low concentration of precious metals (up to $50 \mathrm{mg} / \mathrm{l}$ 
for gold and up to $200 \mathrm{mg} / \mathrm{l}$ for solver). However, a method of electrolytic precipitation of gold has more advantages in case of higher concentrations of gold in a solution [9]. That said, it is relatively easy to recover thiourea used for the interaction with gold, silver, and other metals in the course of the leaching by means of the reduction by metallic iron (after the extraction of gold and silver using adsorbents) or by means of the electrochemical reduction (concurrently with the extraction of metals from a solution). Depending on the composition of solutions and on the method of precipitation, the total recovery rate equals $80-95 \%$ [14].

Further studies on the optimum conditions of the electrolytic gold precipitation from thiourea leach solutions can considerably increase the efficiency and decrease the prime cost of this hydrometallurgical process.

Taking into account the results of studies of Russian and foreign researchers on the topics of importance and possibility of the processing of recyclable technogenic resources with the aim of gold extraction, it can be concluded that this business area is critical for increasing the performance of the Russia's gold mining industry $[5,6]$.

\section{Study on gold precipitation from leach solutions of technogenic gold-bearing raw materials}

Geomaterials sampled from the gold mining technogenic wastes at the placer deposit in Primorsky Kray, having the gold content of 40-60 g/t, were taken as the object of the study. A thiourea sulfate solution was used for the leaching, while a ferric chloride solution or ammonium peroxydisulfate was used as an oxidizer.

The content of gold in solutions was determined by the method of atomic absorption spectrophotometry (AAS) in the laboratory of molecular and elementary analysis of the Institute of Chemistry of the Far Eastern Branch of the Russian Academy of Science. Atomic absorption spectrophotometer Shimadzu 6800 was used to measure Au content. Subsamples weighing $2 \mathrm{~g}$ were used for the studies.

In order to determine the optimum conditions of the electrolytic gold precipitation from thiourea leach solutions, ten (10) experiments were carried out. During the experiments, the optimum parameters of electrolyte composition, overall cathodic current density, electrode voltage, and structural design of an electrolytic cell were selected.

In order to carry out laboratory tests, four (4) types of laboratory units were prepared:

1. An electrolytic cell, made of glass, volume of 0.11 , having one cathode-anode pair (Fig. 1); carbonaceous nonwoven fabric AUT-M-3 with specific surface area of $1200 \mathrm{~m}^{2} / \mathrm{g}$ used as the cathode; a graphite bar used as the anode; power supplied by the laboratory DC 
power source; mixing carried out by means of a peristaltic pump at volumetric flow of $11 / \mathrm{h}$ (experiments Nos. 1-4).

2. An electrolytic cell, made of fiberglass, volume of 60 1, having one cathode-anode pair (Fig. 2); carbonaceous nonwoven fabric AUT-M-3 used as the cathode; a graphite pipe used as the anode; power supplied by a transformer type welding rectifier; mixing carried out by means of a peristaltic pump at volumetric flow of $12 \mathrm{l} / \mathrm{h}$ (experiments Nos. 5 and 6).

3. An electrolytic cell, made of glass, volume of 1.51 , having one cathode-anode pair (Fig. 3); carbonaceous nonwoven fabric AUT-M-3 used as the cathode; a graphite pipe used as the anode; mixing carried out by means of a peristaltic pump at volumetric flow of $12 \mathrm{l} / \mathrm{h}$ (experiments Nos. 7 and 9).

4. An electrolytic cell, made of plastic, volume of 111 , having seven cathode-anode pairs (Fig. 4); carbonaceous nonwoven fabric AUT-M-3 used as the cathodes; graphite pipes used as the anodes; during experiment No. 8 , the mixing was carried out by means of a peristaltic pump at volumetric flow of $12 \mathrm{l} / \mathrm{h}$; during experiment No. 10, the mixing was carried out by means of a mechanical stirrer operating at $100 \mathrm{rpm}$ (an ebonite rotor with a teflon impeller).

\section{RESULTS AND DISCUSSION}

Table 1 shows the results of the experiments.

Table1. Selection of conditions for electrolytic precipitation from thiourea solutions onto electrodes made of carbonaceous nonwoven fabric AUT-M-3

\begin{tabular}{|c|c|c|c|c|c|c|c|}
\hline $\begin{array}{l}\mathrm{N} \\
\mathrm{o}\end{array}$ & $\begin{array}{c}\text { Structural design of } \\
\text { electrolyzer }\end{array}$ & $\begin{array}{c}\text { Leach } \\
\text { solution } \\
\text { composition }\end{array}$ & $\begin{array}{c}\text { Overall } \\
\text { cathodi } \\
\mathrm{c} \\
\text { current } \\
\text { density, } \\
\mathrm{A} / \mathrm{m}^{2}\end{array}$ & $\begin{array}{l}\text { Electrode } \\
\text { voltage, V }\end{array}$ & $\begin{array}{l}\text { Length } \\
\text { of } \\
\text { electrol } \\
\text { ytic } \\
\text { precipit } \\
\text { ation, h }\end{array}$ & $\begin{array}{c}\text { Initial } \\
\text { concent } \\
\text { ration } \\
\mathrm{Au}, \\
\mathrm{mg} / \mathrm{l}\end{array}$ & $\begin{array}{c}\text { Gold } \\
\text { recov } \\
\text { ery } \\
\text { rate, } \\
\%\end{array}$ \\
\hline 1 & $\begin{array}{l}\text { Cell } 0.1 \text { l; mixing } \\
\text { speed } 11 \text { /hour; } \\
\text { number of cathode- } \\
\text { anode pairs - } 1\end{array}$ & $\begin{array}{l}\mathrm{CS}\left(\mathrm{NH}_{2}\right)_{2} 0.4 \\
\mathrm{~mol} / 1, \mathrm{H}_{2} \mathrm{SO}_{4} \\
0.1 \mathrm{~mol} / \mathrm{l}\end{array}$ & 200 & $5.8-6.0$ & 2 & 18.34 & 60 \\
\hline 2 & $\begin{array}{llll}\text { Cell } 0.1 \quad 1 ; & \text { mixing } \\
\text { speed } & 1 & 1 / \text { hour; }\end{array}$ & $\begin{array}{l}\mathrm{CS}\left(\mathrm{NH}_{2}\right)_{2} 0.4 \\
\mathrm{~mol} / 1, \mathrm{H}_{2} \mathrm{SO}_{4}\end{array}$ & 200 & $4.1-4.2$ & 2 & 19.72 & 52 \\
\hline
\end{tabular}




\begin{tabular}{|c|c|c|c|c|c|c|c|}
\hline & $\begin{array}{l}\text { number of cathode- } \\
\text { anode pairs - } 1\end{array}$ & $\begin{array}{lr}0.1 & \mathrm{~mol} / \mathrm{l}, \\
\mathrm{FeCl}_{3} & 0.07 \\
\mathrm{~mol} / \mathrm{l} & \end{array}$ & & & & & \\
\hline 3 & $\begin{array}{l}\text { Cell } 0.11 \text { mixing } \\
\text { speed } 11 \text { /hour; } \\
\text { number of cathode- } \\
\text { anode pairs - } 1\end{array}$ & $\begin{array}{l}\mathrm{CS}\left(\mathrm{NH}_{2}\right)_{2} 0.4 \\
\mathrm{~mol} / 1, \mathrm{H}_{2} \mathrm{SO}_{4} \\
0.1 \mathrm{~mol} / \mathrm{l}\end{array}$ & $\begin{array}{l}180- \\
205\end{array}$ & $3.4-4.15$ & 4 & 21.16 & 65 \\
\hline 4 & $\begin{array}{l}\text { Cell } 0.11 \text {; mixing } \\
\text { speed } 11 \text { /hour; } \\
\text { number of cathode- } \\
\text { anode pairs - } 1\end{array}$ & $\begin{array}{l}\mathrm{CS}\left(\mathrm{NH}_{2}\right)_{2} 0.4 \\
\mathrm{~mol} / \mathrm{l}, \mathrm{H}_{2} \mathrm{SO}_{4} \\
0.1 \mathrm{~mol} / \mathrm{l}\end{array}$ & $\begin{array}{l}180- \\
200\end{array}$ & $4.3-4.7$ & 6 & 21.16 & 67 \\
\hline 5 & $\begin{array}{l}\text { Cell } 601 ; \text { mixing } \\
\text { speed } 121 / \text { hour; } \\
\text { number of cathode- } \\
\text { anode pairs - } 1\end{array}$ & $\begin{array}{lr}\mathrm{CS}\left(\mathrm{NH}_{2}\right)_{2} \\
0.65 \quad \mathrm{~mol} / \mathrm{l}, \\
\left(\mathrm{NH}_{4}\right)_{2} \mathrm{~S}_{2} \mathrm{O}_{8} \\
0.09 \quad \mathrm{~mol} / \mathrm{l}, \\
\mathrm{H}_{2} \mathrm{SO}_{4} \quad 0.1 \\
\mathrm{~mol} / 1\end{array}$ & 250 & $15-16$ & 4 & 10.74 & 20 \\
\hline 6 & $\begin{array}{l}\text { Cell } 601 ; \text { mixing } \\
\text { speed } 12 \text { 1/hour; } \\
\text { number of cathode- } \\
\text { anode pairs - } 1\end{array}$ & $\begin{array}{l}\mathrm{CS}\left(\mathrm{NH}_{2}\right)_{2} \\
0.65 \quad \mathrm{~mol} / \mathrm{l}, \\
\left(\mathrm{NH}_{4}\right)_{2} \mathrm{~S}_{2} \mathrm{O}_{8} \\
0.09 \quad \mathrm{~mol} / \mathrm{l}, \\
\mathrm{NH}_{4} \mathrm{SCN} \quad 0.2 \\
\mathrm{~mol} / 1, \mathrm{H}_{2} \mathrm{SO}_{4} \\
0.1 \mathrm{~mol} / 1\end{array}$ & 300 & $15-16$ & 4 & 16.43 & 42 \\
\hline 7 & $\begin{array}{l}\text { Cell } 1.51 \text {; mixing } \\
\text { speed } 12 \quad 1 / \text { hour; } \\
\text { number of cathode- } \\
\text { anode pairs - } 1\end{array}$ & 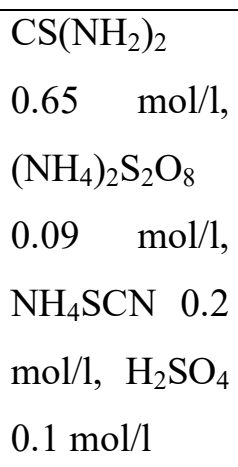 & 1000 & 6 & 5 & 19.32 & 93 \\
\hline 8 & $\begin{array}{lrr}\text { Cell } & 1.51 ; & \text { mixing } \\
\text { speed } & 12 & 1 / \text { hour; }\end{array}$ & $\begin{array}{l}\mathrm{CS}\left(\mathrm{NH}_{2}\right)_{2} \\
0.65 \quad \mathrm{~mol} / 1\end{array}$ & 1100 & 7 & 6 & 22.5 & 87 \\
\hline
\end{tabular}




\begin{tabular}{|c|c|c|c|c|c|c|c|}
\hline & $\begin{array}{l}\text { number of cathode- } \\
\text { anode pairs - } 1\end{array}$ & $\begin{array}{l}\left(\mathrm{NH}_{4}\right)_{2} \mathrm{~S}_{2} \mathrm{O}_{8} \\
0.09 \quad \mathrm{~mol} / 1, \\
\mathrm{NH}_{4} \mathrm{SCN} \quad 0.2 \\
\mathrm{~mol} / 1, \mathrm{H}_{2} \mathrm{SO}_{4} \\
0.1 \mathrm{~mol} / \mathrm{l}\end{array}$ & & & & & \\
\hline 9 & $\begin{array}{l}\text { Cell } 111 ; \text { mixing } \\
\text { speed } 121 / \text { hour; } \\
\text { number of cathode- } \\
\text { anode pairs }-7\end{array}$ & $\begin{array}{l}\mathrm{CS}\left(\mathrm{NH}_{2}\right)_{2} \\
0.65 \quad \mathrm{~mol} / \mathrm{l}, \\
\left(\mathrm{NH}_{4}\right)_{2} \mathrm{~S}_{2} \mathrm{O}_{8} \\
0.09 \quad \mathrm{~mol} / 1, \\
\mathrm{NH}_{4} \mathrm{SCN} \quad 0.2 \\
\mathrm{~mol} / 1, \mathrm{H}_{2} \mathrm{SO}_{4} \\
0.1 \mathrm{~mol} / 1\end{array}$ & 300 & 6 & 6 & 35.88 & 60 \\
\hline 0 & $\begin{array}{l}\text { Cell } 111 ; \text { mixing } \\
\text { speed } 100 \text { rpm; } \\
\text { number of cathode- } \\
\text { anode pairs - } 7\end{array}$ & $\begin{array}{l}\mathrm{CS}\left(\mathrm{NH}_{2}\right)_{2} \\
0.65 \quad \mathrm{~mol} / \mathrm{l}, \\
\left(\mathrm{NH}_{4}\right)_{2} \mathrm{~S}_{2} \mathrm{O}_{8} \\
0.09 \quad \mathrm{~mol} / 1, \\
\mathrm{NH}_{4} \mathrm{SCN} \quad 0.2 \\
\mathrm{~mol} / 1, \mathrm{H}_{2} \mathrm{SO}_{4} \\
0.1 \mathrm{~mol} / 1\end{array}$ & 330 & 7 & 4 & 22.5 & 40 \\
\hline
\end{tabular}

When conducting experiments Nos. 1-4 using simulated leach solutions, it was determined that the gold recovery rate does not exceed $67 \%$ for the overall cathodic current density of $180-200 \mathrm{~A} / \mathrm{m}^{2}$ and voltage of 3.4-6.0 V.

The structural design of an electrolytic cell with the central anode in the form of a graphite bar of $6 \mathrm{~mm}$ in diameter caused too high overall anodic density current $\left(1500 \mathrm{~A} / \mathrm{m}^{2}\right)$ and, as a consequence, intensive thiourea oxidation.

The oxidation of thiourea on the anode is an undesirable phenomenon because it leads to unnecessary consumption of thiourea, contaminates the cathode deposit with resultant elemental sulfur, and contributes to the chemical resolution of precipitated gold.

The last-mentioned process occurs because thiourea can dissolve precious metals in the presence of formamidine disulfide which exhibits oxidizing properties.

In order to decrease the influence of oxidizing processes, the design of the electrolytic cell was modified as follows in the course of further experiments: the anode in the form of a 
graphite bar was replaced with a graphite pipe, while the cathode was positioned in the center of the electrolytic cell.

Experiments Nos. 5 and 6 showed that it is impractical to increase the volume of the electrolytic cell by making it higher because precipitation was observed only in the upper part of the cathode, which resulted in the considerable decrease of gold recovery rate down to 20 $\%$ in experiment No. 5. An attempt to increase the electrolyte ionic conductivity by adding $\mathrm{NH}_{4} \mathrm{SCN}(0.2 \mathrm{~mol} / \mathrm{l})$ in the course of experiment No. 6 led to the insignificant increase of the gold recovery rate up to $42 \%$.

The electrode voltage was $15-16 \mathrm{~V}$. This value is significantly higher than the optimum value (max. $4 \mathrm{~V}$ in experiments Nos. 1-4) and was caused by the big anode-cathode distance (50 $\mathrm{mm})$.

For experiments Nos. 7 and 8, the glass electrolytic cell of 1.51 volume, with one cathodeanode pair, and smaller anode-cathode distance $(20 \mathrm{~mm})$ was used. The overall cathodic current density was $1000-1100 \mathrm{~A} / \mathrm{m}^{2}$ for electrode voltage 6-7 $\mathrm{V}$, which ensured high gold recovery rate of $93 \%$ and $87 \%$ in experiments Nos. 7 and 8 , respectively.

The scaling of experiments Nos. 7 and 8 by increasing the number of cathode-anode pairs up to 7 pieces and the volume of the electrolytic cell up to 111 resulted in the decrease of the overall cathodic current density down to $300-330 \mathrm{~A} / \mathrm{m}^{2}$ while the electrode voltage remained the same at 6-7 V. High contact resistance between carbon fabric and conductors led to the overheating of electrolyte and, as a result, to the decrease in the recovery rate down to $60 \%$ and $40 \%$ in experiments Nos. 9 and 10 , respectively.

\section{CONCLUSION}

In the course of the studies, the below findings were experimentally proved.

The maximum efficiency of gold recovery was achieved under the following ratios of reagents in the process of thiourea leaching: $\mathrm{CS}\left(\mathrm{NH}_{2}\right)_{2} \quad 0.65 \mathrm{~mol} / \mathrm{l},\left(\mathrm{NH}_{4}\right)_{2} \mathrm{~S}_{2} \mathrm{O}_{8} 0.09 \mathrm{~mol} / \mathrm{l}$, $\mathrm{NH}_{4} \mathrm{SCN} 0.2 \mathrm{~mol} / 1, \mathrm{H}_{2} \mathrm{SO}_{4} 0.1 \mathrm{~mol} / \mathrm{l}$.

The maximum gold recovery rate $(93 \%)$ was achieved in the glass electrolytic cell of 1.51 volume, one cathode-anode pair, and the smaller anode-cathode distance of $20 \mathrm{~mm}$, under the below parameters of the electrolytic process: the overall cathode current density $-1000 \mathrm{~A} / \mathrm{m}^{2}$, electrode voltage $-6 \mathrm{~V}$.

Undesirable oxidization of thiourea occurs if a cathode portion is not separated from an anode portion by ion-exchange membranes. 


\section{ACKNOWLEDGMENTS}

The work is carried out with the financial support of the Ministry of Education and Science of the Russian Federation in the framework of the state task in the field of scientific activity № 10.3706.2017/4.6.

\section{REFERENCES}

1. Shumilova L.V. Technogenic deposits as objects of increased negative impact on the environment // Science Time. - 2014. - 8. - pp. 325-356.

2. Krylova G.S., Sedelnikova G.V., Savary E.E., Eliseev V.N. Geotechnological approaches to the processing of stale gold-pyrite raw materials // Mining information-analytical bulletin. 2000. - 5. - pp. 75-77.

3. Afanasenko S.I., Lazaridi A.N., Zolotaya Zhila technogenic dumps // Gold mining industry. - 2010. - 1 (37). - pp. 32-35.

4. Pavlov N.A., Satsuk A.S., Skorik L.F. The review of methods of processing of persistent technogenic deposits // The path of science. - 2017. - 1 (35). - pp. 32-35.

5. Wang C., Harbottle D., Liu Q., Xu Z. Current state of fine mineral tailings treatment: A critical review on theory and practice, Mineral Engineering, 2014, Vol. 58. - pp. 113-131.

6. Evdokimov S.I., Evdokimov V.S. Increase of gold extraction on the basis of joint processing of ore and wastes / / Physical and technical problems of mining. - 2017. - 2. - pp. 160-169.

7. Kholmogorov A.G., Pashkov G.L., Kononova O.N., Kononov Y.S., Plekhanov V.P. Noncyanide solvents for extracting gold from gold-containing products // Chemistry for Sustainable Development, 2001. - 9. - pp. 293-298

8. Meretukov M.A. Gold: chemistry, mineralogy, metallurgy. - Moskow: Ruda and metals, 2008. - 528 p.

9. Lodeyschikov V.V. Technology of extraction of gold and silver from resistant ores. Irkutsk: Irgiredmet, 1999. - T.2. - pp. 511-713.

10. Kholmogorov A.G., Kononov Y.S., Pashkov G.L. Peculiarities of ion-exchange extraction of cyanide gold complexes // Chemistry for Sustainable Development, 2000. - 8. - p. 438.

11. Leonov S.B., Fedotov K.V., Senchenko, E.A. Industrial extraction of gold from ash dumps of thermal power plants // Mining journal, 1998. - №5. - C. 67-68.

12. Haas L.A. Thiourea leaching of carbonaceous gold ores // Mining Eng, 1983. May. P. 462. 
13. Hongguang $\mathrm{Zh}$. The adsorption of gold thiourea complex onto activated carbon / Zh. Hongguang, I.M. Ritchie, S.R.La Brooy // Hydrometallurgy. - 2004. - V.72. - P. 291-301.

14. Kononova O.N., Kholmogorov A.G., Kononov Y.S., Sorption recovery of gold from solutions and slurries. The chemistry, selectivity, technology // Institute of nonferrous metals and material science, 2011. - P.198.

\section{How to cite this article:}

Taskin A V, Yudakov A A, Ivannikov S I, Yelkin O I, Danilov O S, Alekseyko L N. An experimental study on gold precipitation from leach solutions of technogenic gold-bearing raw materials. J. Fundam. Appl. Sci., 2017, 9(2S), 1674-1682. 